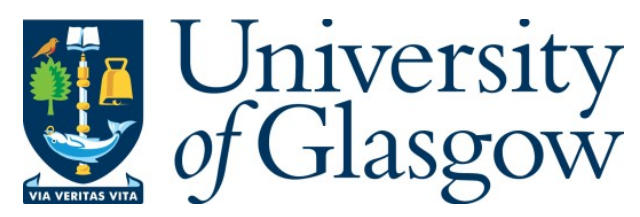

Fraser, A., Armstrong, G. and Hobbs, D. (2021) Policing the Olympic gang: the rise and fall of the Portuguese mafia. Policing and Society, 31(2), pp. 195-208.

(doi: 10.1080/10439463.2019.1700985)

This is the Author Accepted Manuscript.

There may be differences between this version and the published version. You are advised to consult the publisher's version if you wish to cite from it.

https://eprints.gla.ac.uk/205006/

Deposited on: 13 December 2019

Enlighten - Research publications by members of the University of Glasgow http://eprints.gla.ac.uk 


\title{
Policing the Olympic Gang: The Rise and Fall of the Portuguese Mafia
}

\begin{abstract}
Against a backdrop of rising youth violence in the UK, the issue of gang policing has once more risen to prominence. Intense debates surrounding police cuts have led to renewed calls for a 'war on gangs', echoing earlier responses to England's summer of violent disorder in 2011. Drawing on a long-term ethnographic study of policing in the London Borough of Newham, this paper reports on a case-study of gang policing during a similarly fraught political moment. In the run-up to the 2012 London Olympics, a street-based group of minority ethnic youth - the so-called 'Portuguese Mafia' (PGM) - became the primary focus for gang policing in the Borough. Though the group did not self-identify as a gang, their activities were inflated and became the subject of a targeted enforcement initiative. These distortions, we argue, resulted from the influence of political decision-making on the working practices of front-line police officers, amplified in a climate of austerity. Through the reconstruction of this 'natural history', we seek to contribute an empirical account of the ambiguities inherent in police definitions of gangs, and the discriminatory consequences of categorisation. Theoretically, the paper seeks to contribute a critical sociological account of gangs and gang policing that bridges extant objectivist and constructivist readings of gangs through engagement with the Bourdieusian concept of 'field'.
\end{abstract}

\section{Keywords}

Gangs, youth, Olympics, policing, security, labelling, Bourdieu, field.

\section{Word-count}




\section{Introduction}

The issue of youth violence has recently re-emerged as a major political issue in the UK. England and Wales have seen increases in homicide, knife crime, and hospital admissions for stab-wounds in England and Wales, with particular concentrations in London (Allen \& Audickas 2018; ONS 2019). Against this backdrop the issue of policing has risen to prominence, with vocal debates as to the relationship between police cuts and increases in youth violence (Quinn 2019). Renewed rhetoric for a 'war on gangs' (Davenport, de Peyer, Lamuye \& Sheppard 2018) suggests that the tired spectre of gangs is once more being raised as a focus for police intervention (Hallsworth \& Young 2008). These debates echo concerns that emerged in the wake of England's summer of violent disorder in 2011, after which UK Prime Minister David Cameron famously declared 'all-out war on gangs and gang culture.'1 Despite evidence that the extent of gang involvement in the riots was substantially overstated (Guardian and LSE 2012), the Conservative Government pressed ahead with the publication of a policy document, Ending Gangs and Youth Violence (EGYV. (HM Government 2011; Cottrell-Boyce 2013). The same government invested over $£ 10$ million in the programme, instituting a range of gang-specific policies, and the foundation of a series of specialist gang units (House of Commons 2015; Smithson, Ralphs \& Williams 2013). Subsequently, though the nature and form of gangs in the UK remain the subject of intense academic debate (Goldson 2011), the vocabulary of gangs has quietly crept into the working practices of policing. Gangs, like organised crime before them, have become a pragmatic label for police and policy-makers to attract funds, manage risk, and organise resources (Woodiwiss and Hobbs 2009).

In this paper we report on ethnographic fieldwork with a police gang unit before, during and after the London 2012 Olympics to open these processes of definition and categorisation to critical scrutiny. Mirroring the rise and fall of political rhetoric over gangs more broadly, Olympic policing became fixated on a street-based grouping of young men categorised as the 'Portuguese Mafia' (PGM). A loose-knit, highly visible minority ethnic group of around 30-40 young men, originating predominantly from Lusophone Africa, the group congregated in public areas of Newham and engaged in a range of street crime, robbery and drug dealing. The name originated in the summer of 2010 following a series of

1 UK Government (2011. 'PM's speech on the fightback after the riots'. Available at: https://www.gov.uk/government/speeches/pms-speech-on-the-fightback-after-the-riots [Accessed 15th February 2018] 
stop and searches targeting local young men. When asked by the police who they were, one youth replied 'Portuguese Mafia'. Although it was conceded that the name was 'tongue-incheek', it quickly took on a life of its own. Despite not being considered a 'gang' by police, during the Games they became the subject of a dedicated and enduring anti-gang strategy, attracting significant additional resources and investment in a climate of cuts. As gangs faded from the political spotlight, the policing of the PGM was rapidly curtailed.

Through the reconstruction of the 'natural history' (Fuller \& Myers 1943) of this instance of gang policing, we seek to empirically evidence the significance of police culture, bureaucracy and politics in the categorisation of gangs. The paper will be set out in five parts. The first interrogates existing debates surrounding the politics of gang categorisation, setting out a theoretical account drawing on the social theory of Pierre Bourdieu. The second introduces the methodology and research setting, involving a long-term collaborative ethnographic study of policing in the Borough of Newham. The third and fourth follow the rise and fall of the PGM from inside the specialist gang unit responsible for Olympic policing, drawing on extensive field observation and interview data. The fifth and final section reflects on the implications of this episode for the study of gangs and gang policing more broadly. Through this instance of ethnographic storytelling, in which everyday stories call into question established categories (Cameron 2012), we seek to demonstrate the need for a critical sociology of gangs that takes seriously the multiple, contested domains through which the gang is constituted; and the potential for discrimination inherent in gang policing.

\section{Gangs, Policing and the Politics of Categorisation}

In recent years, researchers in the UK has become embroiled in a bruising dispute over ontological meaning over the term 'gang' (Goldson 2011). On one hand, scholars argue that local identity and group conflict are an enduring feature of working-class life in the UK, and as such that territorial 'gangs' are nothing new (Alexander 2000; Hallsworth \& Young 2008; Fraser 2015; Wilson 2016). From this perspective, categorisation of behaviour as 'gangrelated' represents a cynical example of academic entrepreneurialism that cloaks racialised stereotypes, uncritically replicates police agendas, and imposes an artificial and subjective unity on violent street cultures that are inherently chaotic and rhizomatic (Alexander 2008; Smithson, Ralphs \& Williams 2013; Hallsworth 2013; Williams 2015). On the other hand, researchers argue that new street-based groups have emerged for whom the term 'gang' is a meaningful descriptor (Pitts 2008, 2011). From this perspective, business-oriented gangs 
have 'evolved' from previous iterations of street-based groups in the context of austerity, illicit opportunity, and consumer culture (Densley 2014; Storrod \& Densley 2017; McLean, Deuchar, Harding \& Densley 2018). Bridging these positions, which replicate broader debates between objectivism and constructivism in the social sciences (Thibodeaux 2014), requires a broadening of the sociological lens.

The ambiguities inherent in identifying, categorising and policing gangs are long established. As Maxson and Klein (2006, p.4) note, the 'definitional issue has probably been the stickiest one that gang scholars have had to confront'. As a range of scholars have established, the categorisation of individuals as gang-members is fraught with ambiguity (Katz 2003; Fraser \& Atkinson 2014; Bloch 2019). Indeed, Katz and Jackson-Jacobs have characterised the debate as being 'essentially an argument over the correct description of a ghost' (Katz \& Jackson-Jacobs 2004, p.106) - in other words a debate over the correct classification of an amorphous, shape-shifting entity that embodies the projection of deepseated societal fears. Rather than a ghost, however, as an analytic concept the gang may be better considered as what Beck termed a 'zombie category', belonging to a prior stage of modernity but living on regardless: 'living dead' categories which govern our thinking but are not really able to capture the contemporary milieu' (cited in Slater \& Ritzer 2001, p.262).

Seeking new purchase on the term, Van Hellemont and Densley have recently argued that gangs are best viewed through the prism of myth-making (Van Hellemont 2015; Van Hellemont \& Densley 2019). Demonstrating the influence of popular culture on gangs in Brussels and London - notably, the naming of a gang 'New Jacks' after an American movie, or mimicry of characters from The Wire - the authors argue that fictionalised and mediated representations blend with the ideations of police, policy-makers and young people alike (Van Hellemont \& Densley 2019, p.175). As such, gangs must be understood as 'glocalised' formations in which global cultural representations merge with local identifications in a process akin to accounts of 'bricolage' in youth culture (Hebdige 1979). As such, in this multi-mediated world, 'the street scripts the screen and the screen scripts the street: there is no clearly linear sequence, but rather a shifting interplay between the real and the virtual, the factual and the fictional' (Ferrell, Hayward \& Young 2008, p.124). While this process is not unique to the twenty-first century - the 'Tongs' gang of 1960s Glasgow reputedly took their name from a Hollywood film about Hong Kong triads (MacCallum 1994) - this argument draws attention to the ways in which gang fictions are an inescapable element of how people view gangs, and the role of both organisational cultures and mediated stereotypes in the constitution of the gang phenomenon. 
While gang identities may at times be forged in the hinterland between online representation and offline performance, at others they are artificially imposed by police bureaucracy. In an ethnographic study of a police gang unit, Katz (2003) powerfully demonstrates the significance of discretion and ad-hoc working practices on the collection of police gang data. Based on a comprehensive study of processes of gang recording practices, the study found that 'even with elaborate departmental policies (which specify the criteria and procedures for documenting individuals as gang members, groups as gangs, and crimes as gang-related incidents), officers use a substantial amount of discretion in the collection and documentation of gang-related data' (Katz 2003, p.510-511). Like the process of mythmaking described by Van Hellemont and Densley (2019), efforts to pin down gang membership in databases frequently relied on stylistic or aesthetic judgements, rather than self-identification. Indeed, scholarship on such databases has found criteria for inclusion to be 'frighteningly broad' (Siegel 2003, p.224), including clothing, tattoos, or association. As many have argued, the line between street gangs, consumer culture and 'urban cool' is blurry at best (Bjerregaard 2015; Ilan 2015), and there is significant scope for miscategorisation. For example, Bloch (2019, p.5) notes that police criteria for determining gang membership are 'based on superficial and uninformed readings of individuals' markings and other modes of expression', including graffiti-writers who actively repudiate the label, or fans of rap act Insane Clown Posse termed 'Juggalos' (see Linnemann and McLanahan 2016).

It is notable in this context that bureaucratic labelling practices pertaining to gangs may not accord with individual identification, but can nonetheless have 'looping effects' (Hacking 2000). The term 'gang' has both an emic and etic, or 'social and sociological' (Wacquant 1996, p.222) dimension; at once a 'category of practice' for state bureaucracies and a 'category of analysis' for social analysts (Brubaker and Cooper 2000, p.4). Gang identity is therefore best conceived not as a static trait but as forged in a dialectic tension between external categorisation and internal identification. While identification refers to an individual 'suturing' (Hall 1996) to a self-nominated identity - an active, subjective 'claiming' of a specific category of being - categorisation refers to the classification of the individual under a categorical heading; and the 'two need not converge' (Brubaker \& Cooper 2000, p.15). As Brubaker and Cooper note, such tensions between identification and categorisation are not neutral but highly unequal; the 'formalized, codified, objectified systems of categorization developed by powerful, authoritative institutions' (Brubaker \& Cooper 2000, p.15) can act in such a way as to systematically marginalise, disempower and exclude. For example, Goldsmith and Halsey discuss a case in which a loose-knit, familial grouping of 
Indigenous Australians became categorised by police as the 'Gang of 49'. Though their involvement in crime was 'rhizomatic, not diagrammatic', they became subjected to an antigang strategy. When asked where the term originated, an interviewee replied that 'coppers are getting it because they arrested 49 people ... 49 different people .... And maybe some of them were related .... But it's just because there were 49 of them, they arrested 49 ... [that] ... they called it 'the Gang of 49' .... It's not one big gang' (Goldsmith \& Halsey 2013, p.1172). Similarly, Densley (2014) gives an example of a group called the 'Muslim Boys' who took their label from police categorisation. As one police officer recalled: 'we called them the "Muslim Boys" because they were quite literally Muslim boys, which obviously stuck because they started calling themselves by the same name' (Densley 2014, p.527).

It is not coincidental that both of these instances include groups of racialised minorities. Elsewhere, scholars have drawn attention to the ways in which these forms of discretion are implicated in the perpetuation of racial discrimination. Smithson, Ralphs and Williams (2013), for example, note that Black and Asian men in their study were frequently stereotyped as gang members despite active rejection of the term. Similarly, Duran (2009) notes the 'color coding' of stop and search, with coercive forms of policing against Mexican Americans becoming 'legitimated when it was justified by the term "gang" ' (Duran 2009, p.162). Further, as studies of the London Gang Matrix have uncovered, police gang intelligence procedures lack robust practices for classifying individuals as 'gang-affiliated' (Amnesty 2018; Williams 2018). As in the United States, the indicators used 'reflect elements of urban youth culture and identity that have nothing to do with serious crime' (Amnesty 2018: 3). As Williams and Clarke uncovered, these practices are implicated in a gross over-representation of Black, Asian or minority ethnic men in the database (Williams \& Clarke 2016). It is for this reason that scholars have drawn connections between contemporary gang policing and the legacies of colonialism (Nijjar 2018), institutional racism (Fatsis 2019), and the social control of Black communities (Williams 2015). As Alexander notes, the gang 'provides a potent shortcut to understanding youth conflict, offering Hollywood style images of urban chaos and random violence' (Alexander 2008: 5), many of which are racially coded.

In this paper, we suggest that to understand these processes it is necessary to analytically separate the different organisational domains through which the gang phenomenon is constituted. Specifically, we seek to move beyond debates between subjectivism and objectivism - debates which, for Bourdieu, were 'completely fictitious and at the same time dangerous' (Bourdieu 1990, p.34) - through engagement with the concept of 
'field'. For Bourdieu, the social world is composed of a series of semi-autonomous, relational social spaces, or fields, that maintain their own unique logic, power and forms of capital (Bourdieu 1984). These are dynamic sites incorporating both normative and affective dimensions, akin both to a competitive field of sporting activity, and a magnetic field of force (Wacquant 2006). As Bourdieu summarizes, fields are distinguished by 'a relational configuration endowed with a specific gravity' (Bourdieu \& Wacquant 1992, p.16-17), each with a unique internal logic that are subjugated to the 'meta-field' of 'symbolic power' (Bourdieu 1991) through which state bureaucracies assert primary control over language, reproducing systems of racialised and economic inequality (Bourdieu et al. 1999). For Bourdieu, such bureaucratic classification involves:

a power of constituting the given through utterances, of making people see and believe $\ldots$ defined in and through a given relation between those who exercise power and those who submit to it... What creates the power of words and slogans ... is the belief in the legitimacy of words and those who utter them (Bourdieu 1991, p.170)

In the context of the 'police field', Chan (1996) has applied these ideas to the conflicts that exist between changing bureaucratic imperatives and frontline policing. For Chan policing is constituted by forms of the 'interpretive and active' (Chan 1996, 115) cultural knowledge through which officers navigate discretion. These forms of habituated action are difficult to alter but can be subject to change under certain circumstances. In what follows, we seek to elaborate the changes that occurred within the police field (Chan 1996) during the London Olympics, and the symbolic meaning that became consecrated in the term 'gang', as a means of evidencing the ways in which bureaucratic power is implicated in the policing of street-based youth.

\section{Research Site and Methods}

The Olympic Borough of Newham is a city sized outlier borough of approximately 300,000 (Hayman 2011; von Ahn 2006; House of Commons 2010). During its industrial heyday Newham hosted a wide range of dock related and noxious processing industries. Theft and the networks that they engendered were integral to the realities of casual work (Bermant 1975, p.122) which had been the boroughs dominant form of employment, and was only phased out during the 1970s when the docks were in their death throes (Hobbs 1988). Preindustrial Newham was a place where 'deviancy is concentrated and stabilised' (Rock 1973, 
p.30), in which principles of hierarchy and progression were focused on several generations of notorious crime families who were nurtured in the borough, as well as numerous collaborations of part time and professional thieves who plundered the docks (Hobbs 2013). The 'street habitus' (Fraser 2013) of violent youth collaborations were comparatively stable and durable, leading to careers in professional crime (Smith 2005; Fawcett 2013). However, those progressing into serious acquisitive adult crime were rare, and youth collaborations were generally regarded as an unthreatening and temporary phenomenon (Cohen 1973, p.128).

By the time that London was awarded the 2012 Olympics in 2005, however, Newham had suffered nearly forty years of economic decline. Newham represented a fragmented postindustrial hinterland - with high rates of deprivation and unemployment ${ }^{2}$ coupled with serious issues with housing ${ }^{3}$ - onto which an image of 'regeneration' and development was imposed (Paton, Mooney \& Cooper, 2017). ${ }^{4}$ In the aftermath of deindustrialisation, in Newham as elsewhere, '[a]ll that was solid about the post-war welfare consensus - from lifelong employment to welfare safety net - has been actively unravelled and seemed to have melted into air' (MacMahon 2007, p.24). Post-industrial Newham populations could not rely upon the docks or river-related processing and production, and the stable field of criminal entrepreneurialism underwent a shift, with the cognitive and political props of the industrial era becoming realigned to a more fragmented post-industrial political economy. Trade unions no longer dominated local politics, and newly arrived migrants were no longer absorbed into the local political economy or its enabling institutions (Vertovec 2004). With a third of its population 'churning' - moving in, out, or within the borough every year - there was little potential for communality amongst the self-contained informal networks that constituted Newham's population. As Sennett notes ' $[\mathrm{t}]$ here is history but no shared narrative of difficulty, and so no shared fate' (Sennett 1998, p.147). Against this backdrop, the organic street culture of local youth gangs that emerged from a bygone era became increasingly fractured and dissolute (Hobbs 2013).

The episode reported in this paper emerged from a wider study on the policing of sporting mega-events, with a focus on the policing of local residents before, during and after

\footnotetext{
${ }^{2}$ http://www.newham.info/IAS/profiles/profile?profileId=126\&geoTypeId=6\&geoIds=00BB

3 The Newham Housing Survey 2009 identified that 38,800 households were living in unsuitable housing, with overcrowding being the main reason (LBN and NHS Newham, 2011: 85). At that time there were 101,000 dwellings in Newham (LBN \& NHS Newham 2011, p.83).

${ }^{4}$ The 2001 Census reported that Newham was the UK's most ethnically diverse local authority with almost 61 per cent of residents being from non-white ethnic groups (Piggott 2004). There are more than 30 different ethnic communities in the borough, where over 300 languages are spoken (Newham Language Shop 2005).
} 
the London 2012 Olympics (Blinded for review). Qualitative fieldwork took place between 2008 and 2014 in the Borough of Newham, with a particular focus on a 30-month period surrounding the 2012 Olympics (Jan 2011 to June 2013). ${ }^{5}$ The research team, involving two of the co-authors, were embedded with the Metropolitan Police in Newham for the length of the project for the purposes of conducting participant-observation. This enabled access to specialised police documentation, observation of tactical decision-making in situ, attendance at high-level briefings, and carrying out of thirty qualitative interviews with police officers and civilian staff. During the 60-day intensive period of Games policing, ethnographic fieldwork involved daily observations of twelve-hour police shifts. Participant observation was also undertaken at anti-Olympic events and demonstrations in East London, with civil society groups, and community meetings related to the Olympics. The research team were constantly present in Newham, on the streets, in markets, in pubs and in the homes of local citizens, for the duration of the study.

The case study reported draws on the methods and data of this wider study alongside a focused period of qualitative data-collection pertaining to the issue of gang policing, and specifically the PGM. This ethnographic and interview-based fieldwork, carried out by one of the co-authors, focused on the specialist gang/youth violence unit assigned to the area. Observation with this unit extended to more than twenty home visits to suspected gangmembers, ethnographic interviews with both suspects and their parent/guardians, and streetbased fieldwork with outreach 'gang' workers. Several young men categorised as being part of the PGM were informally interviewed via the probation service. In what follows, we relate the constitution of the 'gang' during this fraught political moment through 'ethnographic storytelling' which draws connections between 'the local, the situated and the specific' (Cameron 2012, p.580) within a given historical context. The first section draws on preOlympics fieldwork (January 2011 and May 2012), the second section during and immediately after (June and July 2012).

\section{Reluctant labellers? the emergence of the Portuguese Mafia}

London won the bid for the 2012 Olympic Games partially as a result of promises regarding jobs, housing, opportunities and the overall regeneration of the London Borough of Newham. Very quickly, however, the issue of security came to dominate. Alongside the perceived

\footnotetext{
${ }^{5}$ Support for this period of fieldwork was received from the Economic and Social Research Council (Award Ref. Blinded for Review).
} 
threat from terrorism, gangs emerged as a political focal point. As youth crime policy were reframed in the language of gangs (HM Government 2011), and EGYV strategies were implemented, Newham became listed as one of the nineteen priority boroughs in the highprofile Trident Gang strategy of the Metropolitan Police (London Councils 2012), and was assessed by the Metropolitan Police to be home to three 'Gang Nominals' who were amongst the top 10 in London in terms of their violent potential. ${ }^{6}$ The focusing of the security landscape around the issue of gangs also occurred locally. Newham's Mayor Sir Robin Wales demanded that police, 'Draw up a plan. Destroy them. Keep going till it's no longer worth their while' (Fieldnotes May 2011). Against this backdrop, the gang designation emerged as a pragmatic institutional label through which to focus resources.

In early 2011, in the run up to the Olympics, police in Newham launched a specialist unit to address a series of stabbings and a rise in the use of guns amongst local youth. Despite political attention increasingly focusing on the policing of gangs, local police officers did not initially accede to the new gang designations. Although the term 'gang' was occasionally used, the primary concern was the violence such antagonisms generated. As such the specialist unit was initially designated the Serious Youth Violence (SYV) unit, without mention of gangs. From a local police perspective, the PGM did not constitute a gang. The youths connected to the PGM had no institutional links to the area - arriving in London via Lisbon, with some Lisbon born and others originating in the former Portuguese colonies of Mozambique, Angola and Guinea-Bissau - with some having arrived destitute and claiming refugee status. Alongside those based in Newham, Portuguese speakers located in other parts of London would also travel to the area, especially in the summer months, where they would congregate to socialise and smoke cannabis with local youths in local fast food shops and parks to socialise. Though some of the group engaged in robbery, according to police this was in a far from organised manner.

As the world's spotlight started to fall on the borough in the run-up to the London Olympics, however, the Serious Youth Violence Team rapidly expanded, and within four months was renamed as the Gangs and Firearms Unit (GFU). Subsequently, the term 'gang related' became prominent in the vocabularies of GFU officers. As the head of the unit explained, 'We use the term 'gangs', but they're not really gangs. They're groups of boys and youth who live in the area, hang around together and get involved in serious

\footnotetext{
${ }^{6}$ Confusingly the top 'nominal' in 2012 had no gang affiliation - a fact he celebrated to both police and peers. He robbed - often at gunpoint - street-level drug dealers of any named collective safe in the knowledge that this robbery would not become a crime statistic.
} 
crime... Eighteen months ago this Borough didn't have a gang problem and indeed you were not allowed to use the word 'gang'. Now we can talk about it'. Elsewhere in the Borough, the gang narrative also impacted upon the activities of local professionals tasked with working with local youths. As Gunter notes, for local youth workers gang crime prevention became heavily politicised in an effort to 'clean things up for the Olympics ... it's like we can only work with young people if they are in a 'gang'. I mean what the hell is a gang anyway?' (Gunter 2017, p.300).

Bourdieu draws an important distinction between the external, 'command' level of a bureaucratic field and the internal level of everyday practice (Bourdieu 2005). While new regulatory measures may be introduced at the 'command' level, they may not be recognised or legitimised at the level of practice. As Bourdieu notes, 'the regulatory measures constitutive of that policy are themselves reinterpreted and redefined by a further series of interactions between agents who ... pursue different or antagonistic strategies' (Bourdieu 2005, p.126). A field, therefore, is not an 'apparatus obeying the quasi-mechanical logic of a discipline' (Bourdieu 2005, p.130) but a relational space where cultural knowledge and bureaucratic rules come into conflict, and actors within that space apply discretion. As Chan notes:

\footnotetext{
Bourdieu's conceptions of field and habitus assist our understanding of the relationship between the formal structural context of policing and police cultural practice. Changes in the field (e.g. in the formal rules governing policing) inevitably alter the way the game is played, since habitus interacts with the field, but the resulting practice may or may not be substantially or even discernibly changed. (Chan 1996, p.131)
}

The PGM emerged as the embodiment the changing field of policing in the Olympic period. At a police senior management in Newham in early June 2011, one senior officer considered that the term 'mafia' glamourised their criminality and enhanced their notoriety. Consequently, the word 'mafia' was overlaid in felt-tip pen with 'robbers' on the mugshots at Stratford police station. As the Olympics drew nearer however police were empowered to arrest anyone who was gathering in groups of two or more and refusing to disperse, and as a result of this and the cessation of cold weather many gatherings of local youths left the local mall that was adjacent to the Olympic site and retreated to the public spaces provided by Stratford and West Ham Parks. Generally the local police reported that the PGM were the most confrontational of Newham's youth groups, and this resulted in a number of arrests. According to a wall chart in Stratford police station, the membership of the PGM was predominantly black African but mug-shots also featured two white British youths, two of 
Middle Eastern origin, one Anglo-West Indian and one Anglo-Polish youth. Some of those linked to the PGM commited robberies, and the group could be intimidating to shoppers and park users.

It was clear in the build up to the Olympics that the Metropolitan Police at the highest level were considering gangs, and in particular the PGM, as a major threat to the security of the event. Definitional complexity occupied few police minds, reflecting the existing 'recipe knowledge' of responding to youth violence (Chan 1996). According to the GFU Inspector 'They're a group of mates who meet every day ... We can't decide if they're a gang or not'. The PGM did not feature within the specialist intelligence data collated by the Metropolitan Police, and were generally dismissed by Newham uniformed patrol police as a 'bunch of robbers', and were regarded as the responsibility of the local Robbery Squad. As a senior Newham officer explained:

They (Scotland Yard) want to do 'research and intel profiling' on the Portuguese Mafia. I don't need it thanks very much ... they would rob in the park and they did a whole spate on two bus routes that got crimed-up in both Newham and Tower Hamlets. We got custodial sentences for four of their top men and another three are awaiting trial. This busted them. They are today an ASB (Anti-Social Behaviour. problem ... I said the PGM are not our main problem ... he said he was offering help because he'd heard they were and Newham needed cleaning up because the Olympics were coming.

A turning point in the policing of the PGM took place in May 2012, when a police intelligence report, entitled 'Portuguese Robbers', claimed that the PGM were a group: 'primarily involved in committing personal robberies in Newham... moving into dealing and supplying of cannabis and Class A ['hard drugs', such as heroin and cocaine]'. Most importantly the document claimed that the PGM: 'May well target visitors to the Olympic Games, committing robbery, theft and assault ... as well as putting visitors at risk, they will tarnish the international reputation of London and the MPS [Metropolitan Police].' The emergence of the PGM corresponded directly with the growth of the Olympic infrastructure, and violent criminal gangs became defined as constituting a serious threat to the London Olympics that would dominate the policing of Newham throughout 2012. After a period of incubation within the police organisation, the notion of the gang provided for the police and local council a potent and tangible threat to the 2012 Olympics. It's time had now come. 


\section{A policeable enemy: the rise and fall of an Olympic gang threat}

'It's all Portuguese Mafia this and Portuguese Mafia that. Someone told the Centre that they're going to come out and rob everyone during the Games. The DAC [Deputy Assistant Commander] and Commander then get on the phone demanding to know what the borough's going to do about them' (GFU Inspector.

During the Olympics a Newham crime analyst issued an intelligence profile titled 'Olympic Tasks to Newham Borough in Relation to PM Gang'. The document stated that the PGM were now, officially, a 'gang'. Membership was estimated up to two hundred 'drawn from former Portuguese colonies on the West Coast of Africa', involved 'an active, organised membership' and though' not a "gang" in the traditional sense in that they fight other groups over post-codes, [they] will use extreme levels of force and are very defiant towards SNT [Safer Neighbourhood Team]'. Their violence was 'unnecessary punches to face and blows to the head', they were known to 'intimidate local shopkeepers' and follow off-duty police officers from Stratford police station and 'intimidate them'. The report also claimed that the PGM had girlfriends in a local homeless hostel who moved drugs for them, and wore identical dark clothing to make identification difficult. In recent weeks they had also been 'active' around building societies and banks. One local Detective Chief Inspector felt vindicated by the report and told the researcher uniformed patrol officers that had 'finally recognised our problem with our gangs and especially the Portuguese Mafia... They're always in the Park playing basketball, tops off, ripped, thinking they own the place, fearing the life out of decent people... They're having an adverse effect on the Olympics'. This 'tongue-in-cheek' term, over-written in felt-tip pen by local officers, was increasingly becoming subsumed into bureaucratic intelligence systems, and beginning a life of its own.

In Newham, a database of gang members who allegedly wore coloured bandannas to denote their territorial allegiance was developed. As would be later discovered in studies of the London Gangs Matrix (Amnesty 2018), individuals listed on such databases received negative consequences from housing providers, schools or employment agencies due to datasharing protocols. ${ }^{7}$ By this time there was a deluge of 'intelligence' regarding the PGM, available to inform the actions of police officers. At the evening parade on day five of the Olympics a Newham sergeant explained to provincial officers on Mutual Aid that the PGM had 'been coming here for the past 18 months to two years to target the Olympics. There's 40

\footnotetext{
${ }^{7}$ Particularly notable in this context are the highly racialised nature of these practices (Alexander 2008). Concerns were particualrly raised in Newham in relation to the racialised nature of stop and search (NMP 2012).
} 
or 50 of them. They're hostile to the police... insulting. They attack on bikes and do bag snatches and target women visiting the Olympics. They originate from Burkina Faso via Portugal, but think we're a soft touch compared to Lisbon. Get in their faces... Use Stop and Search whenever you see them. Visit them at home. Let them know we know them... Look at ----- Yesterday he was nicked for robbery. Let's get him deported, we've checked with immigration, and it all depends on nationality and "propensity to commit crime and disorder"'. In the absence of any major incidents, the PGM remained increasingly important within local police narratives, and were reported as switching their activities to other parts of the Borough. The nationality of PGM 'members' were to be reported to the UK Border Agency. ${ }^{8}$

While it was clear that some local youth identified with the PGM, and were involved in robberies, their designation as a 'gang' occurred largely within the ambit of police bureaucratic systems. Midway through the Games two men were arrested in the East Ham district of the borough some four miles from Stratford on suspicion of jewellery snatches, and it was discovered that one of the suspects had recently been placed at the top of the Newham Gang Matrix. Their mobile phones revealed a 'selfie' of a youth holding a shotgun and a fan of $£ 50$ notes, a photo of bank notes totalling a few thousand pounds, and another image of $£ 50$ notes arranged to form the initials 'PGM'. That evening, the DCI told officers that they should 'Get to know the faces of the PGM... get a curfew on them'. Later that night the Mutual Aid officers from a provincial force patrolling Newham in search of the PGM followed a black man in his early 20s, riding a bicycle. When searched he was found to be carrying cannabis in sufficient quantities for him to be taken into the van where he was subject to an illegal strip search which garnered three wraps of crack cocaine. ${ }^{9}$ The young man was arrested and taken into custody. By the end of August five individual associated with the PGM were in custody on remand, three for a post-Games robbery. Rather than organised gang activity, one police officer explained their actions differently: 'They have got fuck all and sit about with nothing to do. Somebody walks past with a phone or a (gold. chain

\footnotetext{
${ }^{8}$ Under Section 44 of the 2007 UK Border Act the police had the right to ask anyone, regardless of the cause of arrest, for proof of nationality. As the DCI enthused: 'It's a massive power rarely used. If they say "Lisbon" as their place of birth - don't accept it - it's the only place they've heard of in Portugal where they claim they're from. If they say "Angola" they might be eligible for deportation. And we can get a Section 18 and search their premises for evidence.'

${ }^{9}$ For further discussion of the use of stop and search, including strip searches, during the Olympics see NMP (2012).
} 
and they think "I'll have that". So they nick it. That don't make them members of a gang' (Fieldnotes May 2012).

The amplified threat associated with the PGM brought with it additional resources. In the Olympic policing weeks, the GFU were provided with previously unavailable resources which enabled them to run two surveillance teams conducting round the clock operations against two notorious drug-dealing individuals (neither of whom was part of the PGM). Further resources came in the form of 'Mutual Aid' officers. In the largest mobilisation of UK police since the 1984/85 Miners Strike, 12,000 officers were drawn from across the UK's police forces to London under the Mutual Aid system (Home Office 2012), many of whom were from outside of London and used to policing very different populations from that found in Newham. As the Olympics progressed without the anticipated public order problems, many underemployed Mutual Aid officers were shifted from overtly Olympic duties in order to offered a considerable manpower boost for anti-gang operations in the wider borough.

The threat posed by the PGM to visitors to the Olympics proved to be negligible. Few visitors to the Olympics strayed far from the heavily policed Olympic Park and the territory most associated the PGM proved to have little attraction to Olympic spectators. By the time the Games commenced Serious Youth Violence (SYV. had decreased by nearly a half, and gun crime down 60 per cent in the previous year. Although the huge police presence around Stratford during the 2012 Olympic Games was a stark symbol of social control (see Manning 1997, 2003), and the source of a great deal of controversy (NMP 2012), that symbol had little to do with reassuring the local public (see Jackson \& Bradford, 2009). As in UK politics more broadly, gang hype was common during the Games, particularly via the conflation of gangs and robbery. The size of the membership, the scope and seriousness of their activities, their status as a gang and the tangible threat that they now posed to the Games had all been inflated. Immediately following the games the PGM continued to find themselves a prime police target. Some PGM associates dealing drugs in Stratford were dealt with by the Newham Crime Squad; others by council-employed Municipal Enforcement officers who patrolled Stratford Park handing out fines to PGM nominals for littering, spitting, and smoking.

Consequently, some members of the notorious PGM, who just months before had been considered to be a major threat to a global sporting event, left the Borough. Some obtained jobs, while others became homeless and moved out of the borough when a hostel for young homeless people was closed down in 2013. Some, unable to call upon any sense of 
fellow gang members for protection, fled from other groups of Newham youth having in the words of the Council's Head of Community Safety, when they 'robbed the wrong people'. Others simply matured out of crime. There were no 'youngers' to take their places, and no legacy. The PGM were not a gang, but a 'policeable' enemy who, post-Olympics, had served their purpose and scattered.

\section{Conclusion}

In the current political moment, in which the spectre of gangs has once again been raised, this instance of ethnographic storytelling acts as something of a cautionary tale. During the period immediately after the London riots of 2011, the Metropolitan Police found itself in a milieu where social order appeared to be in jeopardy (Siegel, 2008). In the run-up to the 2012 London Olympics, commercial and political futures as well as organisational reputations were on the line, and while the risk of terrorism was vague and cloaked with secrecy, gangs were highly visible hooks upon which to hang fears and devote resources: a 'suitable enemy' (Christie 1986) par excellence. Gangs and 'gang talk' (Hallsworth \& Young 2008) therefore served as a tangible focus of urban menace: a bespoke social problem designed to invoke consternation amongst law enforcement and political institutions regarding its threat. These economic and political imperatives within government influenced the field of policing, reframing issues of youthful group disorder through the lens of the gang and resulting in excessive and disproportionate attention to the 'usual suspects' of visible racialised minorities (Smithson, Ralphs \& Williams 2013). The 'improvised news' regarding their organisation served to alleviate uncertainty and ambiguity within an environment where 'grounds for suspicion and sinister hypotheses are never lacking' (Schneider \& Schneider 2003, p.91).

The PGM was a loose knit collection of young men with a penchant for street robbery that emerged from the churn, ebb and flow of 'subaltern insurgent cosmopolitanism' (Harvey 2009, p.283). Like many of the ad-hoc criminal collaborations that emerge in the postindustrial 'street field' (Shammas and Sandberg 2016), criminal entrepreneurialism was a form of capital (Sandberg and Pederson 2008) in an otherwise constrained and limiting social milieu. The imposition of order and organisation on their activities reveals serious flaws in the way that the police identify crime as gang-related, in particular in relation to linking gangs to particular types of criminal activity, and to specific individuals who are perceived to belong to specific ethnic groups (Reiner 2010). These practices of gang 'myth-making' (Van Hellemont and Densley (2019) are not mere instances of cultural bricolage, however, but 
insistent examples of racialised categorisation. By portraying a racialised transgressive minority in terms of 'patternicity' (Shermer 2008), law enforcement were able to mark, frame, and map (Perec 1974), enfolding the essentially chaotic and fluid PGM into an allencompassing gang epoch (Savage 2009; Osrecki 2015). This was exacerbated by the multiplicity of police forces, specialised units and agencies of social control that converged on Newham for the 2012 Olympics.

It should be noted that the PGM did not increase their presence during the Games, and through arrests or displacement actually declined in numbers. What we wish to emphasise is not that the response to the PGM represented a 'moral panic' (Cohen 1973) or that the group themselves were innocent bystanders. The violent reality of the group is not denied, and it is clear that their involvement in street crime rendered them an appropriate object of law enforcement. While some level of police attention was no doubt warranted, however, it is clear that the nature of their collective threat was inflated and distorted by the weary gang label. The construction of the PGM as a gang imposes a coherent, ordered, rational and predictable (Bauman 1999: 79) frame on what was essentially disorganised street culture. As Abt (2019) has recently argued, the gang designation represents an outdated categorisation of increasingly fragmented street-based groups, and police efforts would be better focused on gang violence and violence prevention initiatives rather than gangs per se.

The defragmentation of the contested landscape of gangs between police, street and academic fields (Atkinson-Sheppard \& Hayward 2018), seeks to disavow easy categorisations and embrace complexity, while building a conceptual apparatus that seeks to move beyond subjectivist and objectivist readings of gangs. As Shammas and Sandberg note, there is a need to disentangle the 'properties of the street field from those representations produced by external fields, including the bureaucratic and journalistic fields' (Shammas and Sandberg 2016). Through the application of to both the dynamic street-based contexts through which gang activity is constituted (Shammas \& Sandberg, 2016) and the contested and bureaucratic domain of policing (Chan 1996), debates surrounding academic definition are cast in a new light - as instances of contestation within an academic field of knowledge production that obeys a differing logic to that of policing and the street (Fraser \& Atkinson 2014). Viewed from this perspective, the academic debate over gang definition is less about a changing street culture and more about contestation within an field of knowledge production that obeys a differing logic to that of policing and the street (Fraser \& Atkinson 2014). The open concept of field, 'designed to guide empirical work' (Bourdieu 1990, p.107), can help overcome existing debate while retaining a critical sensibility and empirical focus. 


\section{References}

Abt, T., 2019. Bleeding Out. New York: Basic Books.

Alexander, C., 2000. The Asian Gang: Ethnicity, Identity, Masculinity. Oxford: Berg.

Alexander, C., 2008. (Re)thinking gangs. London: Runnymede Trust.

Allen, G. and Audickas, L., 2018. Knife Crime in England and Wales. Briefing Paper Number SN4304. London: House of Commons Library. Available at: https://researchbriefings.parliament.uk/ResearchBriefing/Summary/SN04304\#fullrepo $\underline{\mathrm{rt}}$

Amnesty, 2018. Trapped in the Matrix: Secrecy, stigma and bias in the Met's gang database. London: Amnesty International.

Atkinson-Sheppard, S. and Hayward, H., 2018. Conceptual Similarities; Distinct Difference: Exploring 'The Gang' in Mainland China. British Journal of Criminology. Online first available at: https://academic.com/bjc/advance-articleabstract/doi/10.1093/bjc/azy051/5156216 [Accessed 4 December 2018]

Ball, R. and Curry, G., 1995. The Logic of Definition in Criminology: Purposes and Methods for Defining 'Gangs'. Criminology 33(2): 225-245.

Barrows, J. and Huff, C.R., 2009. Gangs and public policy: Constructing and deconstructing gang databases. Criminology and Public Policy 8(4): 675-703.

Bauman, Z., 1999. In Search of Politics. Cambridge: Polity.

Bauman, Z., 2000. Liquid Modernity. Cambridge: Polity.

Bermant, C., 1975. Point of Arrival London. London: Eyre Methuen.

Bjerregaard, B., 2015. Legislative Approaches to Addressing Gangs and Gang-Related Crime. In S. Decker and D. Pyrooz, eds. The Handbook of Gangs. Chichester, West Sussex : John Wiley \& Sons.

Bloch, S., 2019. Broken Windows Ideology and the (Mis)Reading of Graffiti. Critical Criminology. Online first: 1-18. Available at: https://link.springer.com/article/10.1007/s10612-019-09444-w [Accessed 25 July 2019]

Bourdieu, P., 1985. The social space and the genesis of groups. Theory and Society 14(6): 723-744.

Bourdieu, P., 1990. In other words: essays toward a reflexive sociology. Cambridge: Polity Press.

Bourdieu, P., 1991. Language and Symbolic Power. Cambridge: Polity Press. 
Bourdieu, P., 2005. The Social Structures of the Economy. Cambridge: Polity Press.

Bourdieu, P. et al., 1999. The weight of the world: social suffering in contemporary society. Cambridge: Polity Press.

Brubaker, R. and Cooper, F., 2000. Beyond Identity. Theory and Society. 29(1): 1-47.

Cameron, E. 2012., New geographies of story and storytelling. Progress in Human Geography 36(5): 573-592.

Chan, J., 1996. Changing Police Culture. British Journal of Criminology 36(1): 109-134.

Christie, N., 1986. Suitable enemy. In H Bianchi and R. van Swaaningen, eds. Abolitionism: toward a non-repressive approach to crime. Amsterdam: Free University Press.

Cohen, P. and Watt, P., eds., 2017. London 2012 and the Post-Olympics City: A Hollow Legacy? London: Palgrave.

Cohen, S., 1973. Folk Devils and Moral Panics: The Construction of the Mods and Rockers. London: MacGibbon and Kee.

Cottrell-Boyce, J., 2013. Ending Gang and Youth Violence: A Critique. Youth Justice 13(3): 193-206.

Davenport, J., De Peyer, R., Lamuye, A., and Sheppard, O., 2018. Met Police chief Cressida Dick declares war on 190 gangs behind violence in London. Evening Standard. Available at: $\quad$ www.standard.co.uk/news/crime/met-police-chief-cressida-dickdeclares-war-on-190-gangs-behind-violence-in-london-a3984691.html [Accessed 25 July 2019]

Densley, J., 2013. How Gangs Work: An Ethnography of Youth Violence. Basingstoke: Palgrave Macmillan.

Densley, J. 2014., It's Gang Life, But Not As We Know It: The Evolution of Gang Business. Crime \& Delinquency 60(4): 517-546.

Duran, R., 2009. Legitimated Oppression: Inner-City Mexican American Experiences with Police Gang Enforcement. Journal of Contemporary Ethnography 38(2): 143-168.

Ericson, R. and Haggerty, K., 1997. Policing the Risk Society, Toronto: University of Toronto Press.

Fatsis, L., 2019. Policing the beats: The criminalisation of UK drill and grime music by the London Metropolitan Police. The Sociological Review. Online first: 1-17. Available at https://journals.sagepub.com/doi/abs/10.1177/0038026119842480 [Accessed 25 July 2019]

Fawcett, M., 2013. Krazy Days. Brighton: Pen Press 
Ferrell, J., Hayward, K. and Young, J., 2008. Cultural Criminology: An Invitation. London: Sage.

Fraser, A. 2013., Street habitus: gangs, territorialism and social change in Glasgow. Journal of Youth Studies 16(8): 970-985.

Fraser, A. 2015., Urban Legends: Gang Identity in the Post-Industrial City. Oxford: Oxford University Press.

Fraser, A. and Atkinson, C., 2014. 'Making Up Gangs: Looping, Labelling and the New Politics of Intelligence-Led Policing'. Youth Justice 14(2): 154-170.

Fraser, A. and Hagedorn, J., 2018. Gangs and a Global Sociological Imagination. Theoretical Criminology 22(1): 42-62.

Fuller, R.C. and Myers, R.R., 1941. The Natural History of a Social Problem. American Sociological Review 6(3): 320-329.

Garot, R. 2010., Who You Claim: Performing Gang Identity in School and on the Streets, New York, London: NYU Press.

Goldsmith, A. and Halsey, M., 2013. Cousins in Crime: Mobility, Place and Belonging in Indigenous Youth Co-Offending. British Journal of Criminology 53: 1157-1177.

Goldson, B., ed., 2011. Youth in Crisis?: 'Gangs', territoriality and violence. Abingdon: Routledge.

Gunter, A., 2017. Youth Transitions and Legacies in an East London Olympic Host Borough. In Cohen, P. and Watt, P., eds. London 2012 and the Post-Olympics City: A Hollow Legacy? London: Palgrave. pp 287-309.

Hagedorn, J., 2008. A World of Gangs: Armed Young Men and Gangsta Culture; University of Minnesota Press: Minnesota.

Hallsworth, S., 2011. Gangland Britain? Realities, fantasies and industry. In B. Goldson (ed.. Youth in Crisis? 'gangs', territoriality and violence, London: Routledge, pp.183-197.

Hallsworth, S., 2013. The Gang and Beyond: Interpreting Violent Street Worlds. Basingstoke: Palgrave Macmillan.

Hallsworth, S. and Young, T., 2008. Gang Talk and Gang Talkers: A Critique. Crime Media Culture, 4 (2): 175-195.

Harding, S., 2014. The Street Casino. Bristol: Policy Press.

Harvey, D 2009., Cosmopolitanism and the Geographies of Freedom. New York: Columbia University Press

Hayman, A., 2011. Newham issues DCLG legal threat. Local Government Chronicle. 21 April. 
Hebdige, D., 1979. Subculture: The Meaning of Style. London: Methuen.

HM Government, 2011. Ending Gangs and Youth Violence. London: HM Government.

Hobbs, D., 1988. Doing the Business: Entrepreneurship, the working class, and detectives in the East End of London. Oxford: Clarendon Press.

Hobbs, D., 2013. Lush Life: Constructing Organised Crime in the UK, Oxford: Oxford University Press.

Home Office, 2012. Statutory Guidance for Police Collaboration. London: Home Office.

House of Commons, 2014. Justice Committee: Joint enterprise follow-up. HC 310. London: House of Commons.

House of Commons, 2015. Home Affairs Committee: Gangs and youth crime. Thirteenth Report of Session 2014-15. HC 199. London: House of Commons.

House of Commons London Regional Committee, 2010. London's Population and the 2011

Census: First Report of Session 2009-10. HC349. London: House of Commons. http://www.publications.parliament.uk/pa/cm200910/cmselect/cmlonreg/349/349.pdf

Ilan, J., 2013. Street Social Capital in the Liquid City. Ethnography, 14 (1): 3-24.

Ilan, J., 2015. Understanding Street Culture: poverty, crime, youth and cool. Basingstoke, Hampshire: Palgrave.

Jackson, J. and Bradford, B., 2009. 'Crime, policing and social order: on the expressive nature of public confidence in policing', The British Journal of Sociology, 60(3): 493521.

Katz, C.M., 2003. Issues in the Production and Dissemination of Gang Statistics: An Ethnographic Study of a Large Midwestern Police Gang Unit. Crime \& Delinquency 49(3): 485-516.

Katz, J. and C. Jackson-Jacobs 2004., 'The Criminologists' Gang', in C. Summer (ed.. The Blackwell Companion to Criminology, pp. 91-124. Oxford: Blackwell.

Linnemann, T. and McLanahan, B., 2016. From 'filth' and 'insanity' to 'peaceful moral watchdogs': Police, news media, and the gang label. Crime Media Culture. 13(3): 295-313.

London Borough of Newham and NHS Newham., 2011. Joint Strategic Needs Assessment 2010: The London Borough of Newham. London: London Borough of Newham.

London Councils 2012., Tackling London's Gangs: A London Councils Member briefing. Available at: https://www.londoncouncils.gov.uk/node/1209 [Accessed 4 December 2018] 
Lorimer, H. 2003., Telling small stories: spaces of knowledge and the practice of geography. Transactions of the Institute of British Geographers. 28(2): 197-217.

MacCallum, R.G., 1994. Tongs Ya Bas. Glasgow: New Glasgow Library.

MacMahon, M., 2007. Bowlby's Contribution for an ASBO Age. London: Crime and Society Foundation

Manning, P. K., 1997. Police Work: The Social Organization of Policing, Prospect Heights, IL: Waveland Press.

Manning, P. K., 2003. Policing Contingencies. Chicago: University of Chicago Press.

Maxson, C. and Klein, M., 2006. Street Gang Patterns and Policies. Oxford: Oxford University Press.

McLean, R., Deuchar, R., Harding, S., and Densley, J., 2018. "Putting the 'street' in gang: place and space in the organisation of Scotland's drug selling gangs." British Journal of Criminology. Online first available at: https://academic.oup.com/bjc/advancearticle-abstract/doi/10.1093/bjc/azy051/5156216 [Accessed 22 Nov 2018]

Newham Language Shop., 2005. 'Newham Council Community Language Survey’ available from http://www.languageshop.org.uk

Nijjar, J., 2018. Echoes of Empire: Excavating the Colonial Roots of Britain's "War on Gangs." Social Justice 45(2/3): 147-161.

NMP (Newham Monitoring Project., 2012. Monitoring Olympics Policing During the 2012 'Security Games', London: NMP.

Office for National Statistics, 2019. Offences involving the use of weapons: data tables. Available at:

https://www.ons.gov.uk/peoplepopulationandcommunity/crimeandjustice/datasets/off encesinvolvingtheuseofweaponsdatatables

Osrecki, F., 2015. Constructing Epochs: The Argumentative Structures of Sociological Epochalisms. Cultural Sociology. 9(2): 131-146.

Palmas, L.Q., 2015. "The Policies and Policing of Gangs in Contemporary Spain. An Ethnography of a Bureaucratic Field of the State.” Sociologica 2.

Paton, K., Mooney, G. and Cooper, V., 2017. Place revisited: class, stigma and urban restructuring in the case of Glasgow's Commonwealth Games. The Sociological Review 65(4): 578-594.

Perec, G., 1997. Species of Spaces and Other Pieces. Harmondsworth: Penguin. 
Piggott, G., 2004. 'Ethnic and religious groups in London', British Society for Population Studies Annual Conference on Ethnicity, Refugees and Group Conflict, 13-15 September.

Pitts, J., 2008. Reluctant Gangsters: The changing face of youth crime. Willan Publishing: Devon.

Pitts, J., 2011. Mercenary territory: are youth gangs really a problem? In B. Goldson, ed. Youth in Crisis? 'gangs', territoriality and violence, London: Routledge, pp.161-182.

Quinn, B., 2019. Met police chief says rising violent crime and officer cuts are linked. The Guardian. Available at: https://www.theguardian.com/uk-news/2019/mar/05/metpolice-chief-cressida-dick-violent-knife-crime-officer-cuts-linked [Accessed 25 July 2019]

Ralphs, R. and Smithson, H., 2015. European responses to gangs. In S. Decker and D. Pyrooz (eds). Chichester: John Wiley.

Ralphs, R., Medina, J. and Aldridge, J., 2009. 'Who needs enemies with friends like these? The importance of place for young people living in known gang areas', Journal of Youth Studies 12(5): 483-500.

Reiner, R., 2010. The Politics of the Police. Oxford: Oxford University Press.

Rock, P., 1973. Deviant Behaviour. London: Hutchinson.

Sandberg, S., 2008. 'Street capital: Ethnicity and violence on the streets of Oslo', Theoretical Criminology 12(2): 153-171.

Sandberg, S. and Pederson, W., 2009. Street capital: Black drug dealers in a white welfare state. London: Palgrave.

Sanders, W., 1994. Gangbangs and Drive-bys: Grounded Culture and Juvenile Gang Violence, New York: Aldine de Gruyter.

Savage, S. 2009., Against Epochalism: An Analysis of Conceptions of Change in British Sociology. Cultural Sociology vol. 3 no. 2 217-238

Schneider J.T. and Schneider, P.T., 2003. Reversible Destiny: Mafia, Antimafia, and the Struggle for Palermo, Berkeley: University of California Press

Sennett, R., 1998. The Corrosion of Character. New York: Norton.

Shammas, V. L. and Sandberg, S., 2016. Habitus, Capital and Conflict: Bringing Bourdieusian Field Theory to Criminology. Criminology \& Criminal Justice 16(2): 195-213. 
Shammas, V., 2018. Bourdieu's Five Lessons for Criminology. Law \& Critique 29(2): 201219.

Shermer, M., 2008. Patternicity: Finding Meaningful Patterns in Meaningless Noise: Why the brain believes something is real when it is not. Scientific American December

Siegel, D., 2003. 'Gangs and the Law.' In L. Kontos, D. Brotherton and L. Barrios (eds.. Gangs and Society: Alternative Perspectives. New York, NY : Columbia University Press.

Siegel, D., 2008. Conversations with Russian Mafiosi. Trends in Organised Crime, 11: 21-29

Slater, D. and Ritzer, G., 2001. Interview with Ulrich Beck. Journal of Consumer Culture 1(2): $261-277$

Smith, R., 2005. A Few Kind Words and a Loaded Gun. London: Penguin

Smithson, H., Ralphs, R. and Williams, P., 2013. Used and Abused: The Problematic Usage of Gang Terminology in the United Kingdom and Its Implications for Ethnic Minority Youth. British Journal of Criminology, 53 (1): 113-128.

Spergel, I. 2009., Gang Databases: To Be Or Not To Be. Criminology \& Public Policy 8(4): 667-674.

Storrod, M. L., \& Densley, J. A., 2017. 'Going viral' and 'Going country': The expressive and instrumental activities of street gangs on social media. Journal of Youth Studies, 20(6), 677-696.

Thibodeaux, J., 2014. Three Versions of Constructionism and their Reliance on Social Conditions in Social Problems Research. Sociology 48(4): 829-837.

Thrasher, F., 1927/1963. [1927] The gang: A study of 1,313 gangs in Chicago (2 ${ }^{\text {nd }}$ edn). Chicago, Ill: University of Chicago Press.

Van Hellemont, E., 2015. The Gang Game: The Myth and Seduction of Gangs. PhD thesis, KU Leuven.

Van Hellemont, E. and Densley, J., 2019. Gang glocalization: How the global mediascape creates and shapes local gang realities. Crime Media Culture 15(1): 169-189.

Vertovec, S. 2004., Cheap Calls: The Social Glue of Migrant Transnationalism. Global Networks 4(2): 219-24.

von Ahn, M. 2006., Newham's Population and the Office of National Statistics Mid-Year Estimates. Unpublished paper. Newham Council, October.

Wacquant, L. J. D., 1996. Toward a reflexive sociology: A workshop with Pierre Bourdieu. In S. Turner (ed.. Social Theory and Sociology. Oxford: Blackwell. 
White, R., 2008. 'Disputed Definitions and Fluid Identities: The Limitations of Social Profiling in Relation to Ethnic Youth Gangs', Youth Justice, 8 (2): 149-161.

Williams, P., 2015. Criminalising the other: challenging the race-crime nexus. Race \& Class 56(3): $18-35$.

Williams, P. and Clarke, B., 2016. Dangerous associations: Joint enterprise, gangs and racism. London: Centre for Crime and Justice Studies.

Williams, R. 1976., Keywords: A vocabulary of culture and society; New York: Oxford University Press.

Wilson, A., 2016. The Same Old Song?: The Contemporary Relevance of Subculture. In D. Hobbs, ed. Mischief, Morality and Mobs: Essays in Honour of Geoffrey Pearson. London: Routledge.

Woodiwiss, M. and Hobbs, D., 2009. "Organized Evil and the Atlantic Alliance: Moral Panics and the Rhetoric of Organized Crime Policing in America and Britain.” British Journal of Criminology 49: 106-128. 